\title{
CROSS-BORDER REPRODUCTION: THE REPRODUCTIVE MARKET IN ANGOLA AND BRAZIL
}

\section{Reproducción transfronteriza: el mercado reproductivo en Angola y Brasil}

\author{
Rosana Machin*; Maria Helena Oliva Augusto*; Douglas Mendosa** \\ * Universidad de Sao Paulo - USP (Brasil); ** Universidad Federal de Sao Paulo - UNIFESP (Brasil) \\ rmachin@usp.br
}

\section{Keywords}

Assisted reproductive technologies

cross-border reproduction Brazil Angola

\section{Palabras clave \\ Tecnologías de reproducción asistida Reproducción transfronteriza Brasil Angola}

\begin{abstract}
Assisted Reproductive Technologies (ART) have grown significantly since the first birth through in vitro fertilization (IVF) in 1978 in the United Kingdom. Despite the massive global expansion of ART services over the past years, they remain inaccessible in Sub-Saharan Africa. In this article, we consider transnational mobility around ARTs by investigating the search for infertility treatment by Angolan couples in Brazil based on empirical material produced on the services of assisted reproduction in Brazil. Quantitative and qualitative methodologies were used. The quantitative online survey, answered by 84 out of 141 fertility clinics in Brazil, showed that there were a significant number of people coming to this country from Africa, Europe and North and South America, with a significant proportion of couples from Angola. To explore those findings, in-depth interviews were carried out with health professionals in Brazil (Sao Paulo) and Angola, and couples undergoing fertility treatments. The study discusses the dynamics involved in seeking treatment from developing countries (south-south relationship), the reproductive strategies and their implications in terms of cultural practices and community.

\section{Resumen}

Las tecnologías de reproducción asistida (ART) han crecido significativamente desde el primer registro de nacimiento a través de la fertilización in vitro en 1978 en el Reino Unido. A pesar de la expansión global masiva de estos servicios en los últimos años, en el África Subsahariana continúan siendo inaccesibles. En este artículo nos centramos en la movilidad transnacional en torno a las ART a través de una investigación sobre la búsqueda de tratamiento de la infertilidad de parejas de Angola en Brasil apoyándonos en el material empírico producido con los servicios de reproducción asistida en Brasil. Para la investigación, se utilizó metodología tanto cuantitativa como cualitativa. La encuesta cuantitativa online, respondida por 84 de las 141 clínicas de fertilidad del país, mostró que hay un número significativo de personas provenientes de países de África, Europa, América del Norte y del Sur en busca de tratamiento de fertilidad, especialmente de parejas de Angola. Con el fin de explorar estos hallazgos, se llevaron a cabo entrevistas cualitativas con profesionales de salud en Brasil (Sao Paulo) y Angola y parejas en tratamiento reproductivo. El estudio discute las dinámicas involucradas en la búsqueda de tratamiento de países en desarrollo (relación sur-sur), las estrategias reproductivas y sus implicaciones en términos de las prácticas culturales y la comunidad.
\end{abstract}

Machin, R., Augusto, M. H. O., y Mendosa, D. (2018). Cross-border reproduction: the reproductive market in Angola and Brazil. Papeles del CEIC. International Journal on Collective Identity Research, vol. 2018/2, papel 198, CEIC (Centro de Estudios sobre la Identidad Colectiva), UPV/EHU Press, http://dx.doi.org/10.1387/pceic.18888 


\section{INTRODUCCIÓN ${ }^{1}$}

Health technologies applied to the reproductive field, particularly those focused on conception, have been incorporated in an accelerated manner in diverse sociocultural contexts. Currently, these technologies make up a global market involving transnational companies, fertility clinics, semen banks, embryo banks and agencies that operate by mediating third-party genetic materials and the surrogate mother. The social biography of such technologies has developed from the private sector, with little regulation or social control, favoring the establishment of market logistics.

Sub-Saharan Africa is often described as having low accessibility to Assisted Reproductive Technology (ART) services despite the massive global expansion of these techniques in recent years. Inhorn and Patrizio (2015) note that seven out of the fifteen nations have a single IVF (in vitro fertilization) clinic. The exception in this context are Ghana, Nigeria and South Africa that seem to have better structured services. This picture of ART shortages contrasts with the high estimate of infertility in the region. According to Inhorn and Patrizio (2015: 414), high rates of infertility are found in Angola, Cameroon, Central African Republic, Equatorial Guinea, Gabon, Liberia, Mozambique and Sierra Leone. Larsen (2000) estimates an average infertility rate between $5 \%$ and $23 \%$, which may reach $29 \%$ in some countries. According to WHO, more than $85 \%$ women's infertility in Sub-Saharan Africa is caused by infections, compared to $33 \%$ in the rest of the world (Inhorn and Patrizio, 2015). Approximately $70 \%$ of pelvic infections are sexually transmitted.

Recent studies in Ghana, Mali and Uganda have examined the main difficulties to establish IVF clinics in these countries (Gerrits, 2016; Hörbst and Gerrits, 2016). These include problems related to existing health infrastructure (equipment production, medicines, etc.), unavailability of qualified professionals, lack of financial resources, and ethical, legal or religious issues. The authors emphasize the importance of established dynamics among clinics in developed countries, especially in Europe, involved in the creation of services in these African countries, and in particular, the transfer of technology and the training of human resources. Thus, while many health technologies have been introduced

\footnotetext{
${ }^{1}$ The authors thank the São Paulo Research Foundation (FAPESP), whose financial support made this study possible (process 2015 / 20543-4).
} 
into the region as part of cooperation initiatives with international agencies, ARTs are most often established in the private sector at the initiative of talented entrepreneurs (Hörbst and Wolf, 2014). The introduction of technologies by the private health sector is closely related to the potential profitability of the reproduction market in these countries. In the Sub-Saharan region coexists: first, a high estimated levels of infertility prevalence; second, parenthood being valued as an essential attribute of marital relationships; and finally, the emergence of a growing middle class able to afford the high prices involved in these treatments (Hörbst and Gerrits, 2016).

In Angola, the 25-year civil war destroyed much of the country's infrastructure and featured large scale massacres and population movements, both inside and outside the country. The cease-fire took place in April 2002 and opened up the possibility for reconstructing the country (Baptista, 2008). However, there are still great challenges that need to be overcome to organize its health system. According to a 2016 WHO report, there is a lack of access to primary health care, especially in suburban and rural areas, including the shortage of available, qualified human resources. This insufficient health coverage is due to the poor maintenance of the basic health units. Alves et al. (2017) state that there is a poor distribution of personnel in some areas, and that there are no assisted reproduction services. Additionally, there is a shortage of financial resources and an inadequate funding model. Faced with a lack of assistance in sexual and reproductive health care, particularly in the areas of abortion, sexually transmitted infections and HIV/AIDS, we can also consider the significance of these factors in the occurrence of infertility that is due to inadequate health care conditions.

Motherhood is highly valued in Angola. In 2013, the country had a fertility rate of around 5,9 children per woman of reproductive age (WHO, 2016). Interviews conducted for this study with Angolan community leaders resident in Brazil tell us that polygamy does not exist legally, but it is still culturally accepted. It is not uncommon that, in the absence of children after marriage, the husband has children with other women to attest his ability to form a family and have progeny. Infertility and/or absence of children are perceived as major failures and there is considerable pressure from the extended family for the arrival of a baby.

It is important to mention the connection between the high prevalence of infertility in cultures where fertility is also significant. Inhorn (2007) 
characterizes this problematic situation as "the fertility-infertility dialectic". Countries with low resources and high-fertility can provide elements so that we can better explore the context of infertility. Perceived values associated with conception, maternity, paternity, sexuality, gender relations, reproductive processes and risk perception figure as key dimensions requiring our attention. Discussing infertility in Sub-Saharan Africa, Boerma and Mgalla (1999) note that infertility in marriage is highly likely to lead to extramarital relationships - with arrangements, for example, to ensure that a woman becomes pregnant if it is the male who is infertile-, just as there is an important justification for divorce or for the husband to include a second (or additional) wife in an infertile union. This situation has stimulated the search by Angolan couples for reproductive treatments in South Africa, Portugal and Brazil.

In the processes of expansion of the use of reproductive technologies in diverse situations and territories, we focus on what has been called 'cross-border reproduction', 'fertility travel' or 'reproductive tourism' (Cooper and Waldby, 2014; Culley, Hudon and Van Rooij, 2009; Goodwin, 2010; Ikemoto, 2009; Inhorn and Gürtin, 2011; Krolokke, Foss and Pant, 2012; Pfeffer, 2011; Shenfield et al., 2010; Spar, 2005). The terms used tend to refer to quite different situations. 'Reproductive tourism' or 'fertility travel' are inappropriate because they confuse an often uncomfortable and stressful practice with leisure activities. In addition, many people would certainly prefer to remain in their own country if there were favorable circumstances.

It is our belief that the term 'cross-border reproduction' is best suited to the specificity of the analysis developed regarding the interface between two developing countries, in a south-south interaction. In this sense, it allows the approach to address situations related to emergent, distinct dynamics, which may involve the effective movement of health professionals, of men and women in search of ART, of genetic material (semen, ova) donors, and of people searching for surrogate mothers as well as the import and export of frozen gametes and embryos.

Many previous studies have focused their investigations on practices involving either the search for treatment by residents of developed northern countries (Europe, North America) with third-party genetic material, or the search for an acceptable surrogate mother in southern countries (especially Southeast Asia) (Banerjee, 2014; Gürtin and Inhorn, 
2011; Ikemoto, 2009; Nahman, 2011; Spar, 2005; Whittaker, 2011). Alternatively, these studies addressed interconnections between countries in the Middle East (Inhorn, 2007; 2011). In comparison, the connections and movements of those seeking treatment among southern countries have been poorly documented.

According to Inhorn and Gürtin (2011), the main reasons identified for this transnational search for ART could be grouped into four categories, all related to the country of residence: one, legal or religious prohibitions; two, considerations related to the costs involved and nonavailability of ART; three, doubts regarding the quality, safety and outcome of procedures; and, four, personal preferences (the existence of family support, for example). Other important elements in the selection of a destination country are the existence of a good tourism structure and criteria related to entry visa, government policies concerning support for medical treatment of foreigners, and the availability of translators in their native language (Whittaker, 2011).

We emphasize, at this point, the importance of developing studies that focus on the specificity of the processes involved to show the links, collaborations, confrontations, dissensions and fragilities of crossborder reproduction (Fonseca and Sá, 2011; Latour, 1993). Based on this idea, we focused on transnational mobility around ARTs by investigating the search for infertility treatment by Angolan couples in Brazil.

\section{The CONTEXT OF ART IN BRAZIL}

In the medical field, particularly regarding biomedicine, innovations have been introduced in Brazil through public or university-linked services, due to the high cost of technological research and the necessity of qualified personnel for its development (Augusto, 1986). Despite this situation, ARTs were introduced in the 1980s almost exclusively by private medicine's initiative, even though some of its specialist doctors and professors continued activities linked to universities (Barbosa, 1999). Consequently, the majority of ART services continue to be performed by the private sector as these services are not covered by the Brazilian Unified Health System (the SUS). 
There are, nevertheless, some services, most of which are linked to universities, that serve those unable to afford a private clinic $^{2}$. These services are subject to various restrictions in treatment (related to the maximum age for accessing the program, for example); there is a high demand, a necessity for the users to pay for some expenses (medicines), and often, only low complexity techniques, such as artificial insemination, are offered. Many of these services have waiting lists which can range from 300 to 1.500 patients and treatment waiting times vary from around 6 months to 4 years (Souza, 2014). ARTs in Brazil are funded through the disbursement of private resources of interested parties. However, it should be noted that over the past fifteen years, these practices have become accessible to a larger proportion of society because of a fall in the cost of procedures. In addition, to help couples cope with the still-high costs, several services have created low-cost IVF treatments, offering discounts to a group of interested parties and with fewer restrictions.

The majority (55\%) of clinics are concentrated in southeast Brazil ${ }^{3}$, the country's richest region, and offer highly complex techniques (micromanipulation, intracytoplasmic sperm injection/ICSI) (Anvisa, 2016). According to the Latin American Network for Assisted Reproduction (REDLARA ${ }^{4}$ ), in 2015 there were 61 clinics registered in Brazil (REDLARA, 2015), and between 1990 and 2011, 44,4\% of the total number of births using ART in Latin America were in Brazil, followed by Argentina and Mexico, with 22,4\% and 13,2\% respectively, and Chile with $5,8 \%$.

The development of ARTs in Brazil was marked by a context of low regulation (Diniz, 2003; Machin, 2014). There is no specific state law for these practices. It is noteworthy that since the mid-1990s, there have been specific initiatives to regulate the use of ART; initially, some were adopted by parliamentary committees but did not progress further.

To safeguard practices, Brazilian doctors follow ethical rules in the form of deontological norms relating to the techniques used in assisted

\footnotetext{
${ }^{2}$ The university services are mostly maintained by state or federal public funds.

${ }^{3} 30 \%$ of the clinics operate in the State of São Paulo.

${ }^{4}$ Created in 1995, REDLARA is a network of assisted reproduction centers in Latin America. It carries out the accreditation and cataloguing of centers and their results. In 2012,172 centers were in the network and they were responsible for 47,326 procedures in the region. It reports covering about $80 \%$ of the cycles of reproduction (REDLARA, 2015).
} 
reproduction. Since 1992, guidelines have been established by the Federal Council of Medicine (CFM) "for the use of assisted reproduction" (1957/10, 2013/13, 2121/15). In 2013, the council issued resolution number 2.013, changing, notably, for whom the techniques are intended (CFM, 2013). This resolution extended the types of recipients, to which the techniques could be applied, to "all capable people" and makes it explicit that "use is allowed in homosexual relationships and for single persons". It replaced the old definition of techniques, previously considered as being focused on solving infertility problems, with "assist in the resolution of human reproduction problems, facilitating the process of procreation" (CFM, 2013: 3). In the last edition of the resolution (2121/2015), the use of techniques within homosexual relationships and with single people is explicitly included. This wording appears to convey a context of apparent universality in the eligibility of access. However, since ARTs are not available within the scope of the public health system, private clinics are the only option and so there remains a significant economic barrier.

In 2005, the National Health Surveillance Agency (Anvisa) created the National Embryo Production System (SisEmbrio), a national compulsory registry of stem cells, tissues and banks, and an information system including records of the production of human embryos by IVF. Anvisa is a regulatory agency linked to the Ministry of Health. According to the agency's data, in 2016, 141 services reported 33,790 cycles of assisted reproduction, with 66,597 cryopreserved embryos (65\% of them coming from clinics located in southeast Brazil) (Anvisa, 2017).

In Brazil, the commercialization of third-party genetic material is prohibited. By law, donors may not receive any sum to prevent the characterization of a business relationship (CFM, 2013). There are only two semen banks in the country and they are responsible for providing supplies to various clinics, and also to other countries in Latin America. The low availability of semen has led clinics to import supplies from the United States, especially for procedures involving lesbians and single women (Machin, 2014). Specific legal authority is required to import semen; there were 33 consents in 2013, 198 in 2014, 377 in 2015 and 436 in 2016 (Anvisa, 2016) ${ }^{5}$. As for the ovules, the current regulations of the

\footnotetext{
${ }^{5}$ One significant example of this growth was the opening of an office in Sao Paulo by one of the largest semen banks in the United States, hoping to facilitate the import of genetic
} 
Federal Medical Council allow the donation of eggs from young, fertile women, who use the service for the freezing and preservation of their eggs for a possible future pregnancy. Nonetheless, IVF clinics have reported low egg availability for third-party procedures in the country.

\section{Methodology}

The present study is based on empirical material produced in the frame of a broader research focused on assisted reproduction services in Brazil in 2013, and the main implications of their practices in the field of health technologies resulting from regulatory changes. Due to the nature of the study, we chose both a quantitative and qualitative methodology. In this article, we use the empirical data produced in the qualitative research carried out using the technique of semi-structured interviews.

Regarding the broader study, we used a cross-sectional questionnaire, with a non-probabilistic sample and subsequent multivariate statistical analysis. Assisted reproduction clinics in Brazil were the units of analysis, and we aimed to discover their distribution, available services, technologies employed, practices performed, population served and existing forms of funding. We opted to use the REDCap Program, a webbased application for the construction and management of online surveys and databases. The questionnaire addressed the characterization of services, care and recent changes in practices. In order to define the clinics to be investigated, we surveyed their services based on the cross referencing of some databases: medical societies (Brazilian Society for Assisted Reproduction), REDLARA (Latin American Network for Assisted Reproduction) and SisEmbrio (National Embryo Production System Registry of the National Agency of Sanitary Surveillance, Anvisa). The SisEmbrio registry, established in 2008, only includes clinics that perform highly complex techniques.

This procedure was adopted as there is no data on how many centers there are in the whole country. We analyzed 84 questionnaires, completed by the clinics, about services in operation in the country, for the years 2016 and 2017. The questionnaires returned correspond to $59.2 \%$ of the clinics actively performing procedures of high complexity. Among those interviewed, 85\% affirmed they had attended non-

material. Also, two existing Brazilian semen banks have become representatives of other United States banks. 
Brazilian residents in the previous two years (2014 and 2015). Patients' countries of origin were mainly Angola, the United States, Portugal and Italy. Based on this information, semi-structured interviews were conducted to understand the phenomenon of the flow of couples from Angola.

Qualitative interviews were conducted with key professionals who had been defined by their position in the field and linked to specialist services (gynecologists, embryologists, psychologists), Angolan community leaders living in Brazil, and Angolan couples who had performed reproductive procedures in Brazil. We undertook 19 interviews: 10 with health professionals, 2 with community leaders and 7 with Angolan couples who had undergone treatment or were currently doing so ${ }^{6}$. The interviews were recorded and later transcribed verbatim. Comprehensive reading of the transcriptions was carried out and thematic categories were constructed. Data from all subjects were reexamined to check these themes in relation to their meanings.

\section{IN SEARCH OF ART IN BRAZIL}

The largest flow of Angolans to Brazil, motivated by their desire for health treatments, took place around 2005, coinciding with the democratization of the country and its economic development, as pointed out by Angolan community leaders interviewed for this study. Although we did not obtain numerical data to enable us to quantify this process, the community leaders interviewed commented that in the periods of most dense movement of people, regular flights landed in the city of São Paulo, carrying roughly four hundred Angolans. Nearly half of these people were looking for healthcare, including fertility treatments.

There was a very big movement here in São Paulo. I can say with conviction that of $100 \%$ of the Angolans who came here, (...) $50 \%$ came intending to make purchases and the other $50 \%$ came with the intention of getting this type of service or any health-related service. Not necessarily just reproduction.

\footnotetext{
${ }^{6}$ To preserve the anonymity of the interviewees, a code was created. The leaders of the Angolan community in Brazil can be identified with the letter $\mathrm{L}$; the patients with the letter $\mathrm{E}$ and the husband of one patient with the letter $\mathrm{C}_{\text {; }}$ and the medical specialist with the letter M. In this article we use the following interviews: L1 and L2 for the two Angolan community leaders living in Brazil; E1 and E2 for the Angolan patients who had undergone treatment or were currently doing so, and C1 for the Angolan husband of E2; and, M1, M2 and M3 for three ART medical specialist interviewed.
} 
Health too. Unfortunately, our health system is somewhat ailing, so those who are able to come here, if they need a health service, come here, to Brazil. (L1)

This constant flow of Angolans searching for health treatment led to the establishment of a network by the Angolan community living in Brazil. The role of this community, in supporting those who sought health treatment, was frequently stressed in the interviews, particularly in cases where women stayed on their own for treatment in Brazil and needed financial help from their husband and family who remained in Angola. In most cases, the help came via an acquaintance travelling to Brazil who would bring financial help.

It is not possible to understand the extent of this support or its possible involvement with ART clinics. However, community leaders observed that there was a constant connection between couples in Angola interested in ART and the Angolan community resident in Brazil.

The Angolans who live here, with this movement [of people], generated a certain economy, and then created for themselves some types of work, such as 'the guide'... The socalled 'guide' was the person who provided guidance to, let's say, their passenger, their client, for everything: to make purchases, to ask the doctor questions, anything she might need. (L2)

The search for treatment usually involved a trajectory in other countries such as Portugal or South Africa. The cultural proximity of the language is referred to as an important element in the choice of Portugal. In the case of South Africa, there is mention of geographical proximity and the existence of clinics where the Portuguese language is spoken. The issue of costs, lower than those in Brazil, was also noted. The decision to go to Brazil was based on previous success stories and personal recommendations by people who have already received treatment in the country:

Because it doesn't exist, at least in Angola, a doctor [that performs ART]. When we went to South Africa, we didn't go to a doctor who said: 'Look, in South Africa I know A, B, C, D, which I can pass on'. That didn't happen. Nor has it happened in Brazil. This is something I happen to have asked myself. Why do these collaborations not exist between Angola and Brazil at the medical level? (...) We were directed exactly in this matter by word of mouth. (E2, 32 years old, 6 years of treatments in South Africa and Brazil) 
I was about 2-3 years like this, getting ready to go abroad. And the first chance I had was Portugal. I went to Portugal. (...) I went to a private clinic, too. At that time, I went on the guidance from someone, a relative who had also gone to Portugal to try to have insemination. I returned to repeat it [the procedure] and then it didn't work. Didn't work. So that's when I immediately went to Brazil. Because I had a cousin who was also there, in São Paulo, who also had a lot of difficulty, but she got there and succeeded. She started a gestation, so then she calls me and says: 'Cousin, leave Lisbon and come here.' (E1, 47 years old, 10 years of treatments in Portugal and Brazil)

The existence of an agency of Angolan community members for the recommendation of clinics and suitable accommodation should also be noted.

How did we find out about South Africa? Oh, we asked around, and as we are from a church, the pastor there recommended someone. We were guided by the pastor of our church. We achieved it there in South Africa. (C1, 37 years old, husband of E2 for the last 10 years)

Most of those who come to Brazil for treatment are members of the upper middle classes in Angola. In order to have these treatments, they usually establish temporary residence in the country, most of the times with other women receiving treatment, in shared housing known as "Angolan republics". When the treatment results in pregnancy, they remain during gestation to give birth in Brazil, returning to their country a few months later.

Every time I speak to someone, it was the husband who had a good social situation and supported the wife to stay for about a year, two years in Brazil. That was the average. But there were people who ended up staying a little longer: 3, 4 years. Then they finally give up because it hasn't worked, see? It's expensive. It was generally advisable for the woman to stay until the whole process was finished, because it required some care. Understand? And after finding out that she was actually pregnant, it did not necessarily mean that everything was okay. It was very delicate. She had to have a doctor for follow-ups, a career. Then most chose to stay until the end of the pregnancy. The majority, as far as I could see. (L2)

Among the reasons that would facilitate the search for treatment in Brazil, we can highlight: the ease of speaking the same language, the link and cultural identity with the country, confidence in the ability of 
medical professionals, and the reception and support of the Angolan community in Brazil. As this doctor says:

\begin{abstract}
Language and cost. I'll be very honest with you. I think we've received a number of outpatients because we have good medical services; we're as egalitarian as anywhere on the planet. I've no doubt of that. I'd say that it is more egalitarian than a good part of the world, especially the state-owned medical services. Europeans, I think, should lose out a little to North America. Compared to the Europeans, I've no doubt that we are better. I think private clinics are even better because there is a very large demand in the market. The cost to people is cheap, if you compare treatments out there. (M3)
\end{abstract}

Specialized literature has pointed out that there are challenges related to the availability of ART in many countries of the African continent. This is due to structural instability, political and legal systems, scarcity of financial resources and the unavailability of health professionals qualified in ART (Gerrits, 2016; Hörbst, 2016; Hörbst and Gerrits, 2016; Hörbst and Wolf, 2014). Gerrits (2016) focuses on the importance of transnational connections and collaborations of ART providers for establishing clinics in Ghana. Hörbst (2016) explores the establishment of IVF provision in Mali and Uganda, also highlighting the importance of transnational networks, especially with Europe, for success in establishing clinics in these African countries.

In the case of Angola, the absence of ART and practitioners in the country, plus the financial conditions, mobilized the search for treatment in Brazil and stimulated the creation of a clinic in Angola in collaboration with Brazilian professionals. In fact, the experiment began with an invitation from an Angolan businessman to a Brazilian doctor specialized in ART, who had been a doctoral student and had spent some time at an IVF clinic in Spain. The project began to take shape in 2008 due to the already intense flow of couples from Angola to Brazil in search of reproductive treatment. The doctor moved his home to Angola, taking with him a team from Brazil comprised of an embryologist, a nurse and administrative support personnel:

(...) and in 2015, I went to Africa, to Angola. I stayed there to set up a human reproduction center. A long project, practically from 2008, we started to develop this project there. And the investor did not limit resources. He set up the sort of clinic that I had not seen here in Brazil. He set up an 
impressive clinic. He bought everything it needed and didn't need. (M1)

Siento During 2015, the team arrived to attend about a thousand patients, conducting investigations into the causes of their infertility. However, the patients could not afford an IVF cycle.

We set up [the clinic], it's just that we couldn't make it work. So, I spent a year there and for the entire year I was there, with the clinic already completed, we could not do any cycle of in vitro fertilization. (M1)

The professional mentioned various difficulties that impeded the development of the practices. After a year, he decided to give up the project and return to Brazil.

So, we could not buy supplies, because they come from
abroad. Everything comes from abroad. They do not
manufacture anything [in Angola). Second, there were
political obstacles. An extremely corrupt country, extremely
corrupt, to the core. So, everything that needed to be done
needed authorization (...) and a payment. (...) They did not tell
us directly, but we felt that this was happening. Today we look
back with more affection because it was an adventure and
such. But at the time it was very frustrating, it was very hard to
make the decision to leave. Making the decision to go was
very difficult. (...) We said: 'No, we will insist on just another 3
months'. Then it was 3 months later and nothing had
happened. We would insist on another 3 months. It was
difficult, a difficult year. (M1)

Other health professionals interviewed referred to the existence of other projects currently in operation in Angola, with Brazilians participating. One of these had the involvement of an embryologist from Brazil. This professional would travel to work intermittently in Luanda, staying for about a month to perform all the laboratory procedures in a clinic, returning afterwards to Brazil. Nevertheless, it seems that even initiatives such as this did not reduce the flow of couples to Brazil seeking treatment, as one interviewed doctor observes.

As far as I know, this clinic does not work very well. Well, we keep getting patients, quite a lot. A large number, yes. I think it's the number one country for foreigners that we attend here. For example, at the moment, I'm attending, I think, about four Angolan couples. There's one from Italy. There's one from China (...) so the Angolans are the majority, right? (M2) 
A statement made quite frequently is that Angolans spend a lot of time in Brazil, end up living there, attending public services, and getting medication from the SUS that is often out of reach for Brazilians.

Some of them resolve, when they get pregnant, to have the prenatal and delivery here, so sometimes they stay one, two years. Until the baby is born. They stay here for a very long time. (M2)

Other health professionals interviewed also consider that, although the treatment is private and paid for by the couples, when a pregnancy occurs, prenatal care and childbirth often take place in Brazil's public health system, the SUS. The Brazilian health system has universal access and residents can make use of it. Thus, even in a situation of transnational movement for reproductive treatment in the private sector, there is a connection with the public sector. This practice may be linked to the fact that, even with the financial resources to pay for private treatment, staying for a long period of time outside your country may involve costs that are more difficult to bear. In addition, the evaluation of the quality of care by the Brazilian health system is very good, despite the recurrent difficulties faced.

\section{5. "I WAS PRACTICALLY ALONE, WITHOUT FAMILY"}

Based on interviews with couples from Angola who were treated in Brazil, we describe two emblematic cases of reproductive treatment search in that country.

Case 1 - E1, Angolan, married, 47 years old. She underwent pregnancy treatment in Angola from the age of 35, without success. She could get pregnant but could not complete gestation. She went to Portugal on the recommendation of a relative and got pregnant twice but suffered miscarriages. She came to Brazil in 2015 on the recommendation of a cousin, who had been treated successfully. At the age of 45 , she underwent a procedure with eggs donated by a Latin American woman who had supplied a photograph of her child. She stated that the clinic had several donor options to choose from. She got pregnant and gave birth in the Brazilian public health system because of her lack of resources for continuing at the private clinic. She told us: "When I think of Brazil, I only see a lot of good things, a lot of blessings, God's grace. I always had a Brazilian hand extended to help me. Because I was practically alone, without family". 
Case 2 - E2, Angolan, married, 32 years old. After one year of marriage, she and her husband sought a clinic in Angola because pregnancy had not occurred. Both were treated (the woman for irregularity of cycles and the husband for varicocele), but pregnancy still did not happen. They decided to go to South Africa in 2012, on the professional recommendation of the pastor of their church. But again, the treatment did not work. They decided to come to Brazil in 2014 on the recommendation of an acquaintance. When they arrived in the country, they were taken to a gynecologist who did not specialize in ART. They did not agree with the proposed procedure (surgery for tubal clearing) and decided to find a reproductive clinic. She got pregnant at the first attempt. After contact with other Angolans in this clinic, she moved to an Angolan residence in the center of the city to await childbirth in a public health system hospital. She told us: "Because of the African concept that not having children is disrespectful to the family, to the land, to the world, if, in the end, you reach 30 years old without children, you are nicknamed 'the thirty'; someone sterile, who does not make children." (C1).

The main aspect that we highlight refers to a situation similar to that found among patients with low financial resources and inadequate assistance for women's health problems (Barbosa, 1999). Patients have difficulty in getting an accurate diagnosis of the cause of their infertility and this frequently leads them to undertake long term treatment in healthcare services.

Urban middle-classes constitute the typical profile of couples in search of reproductive treatment. However, some couples need more extended financial support from their families to be able to afford the costs involved in the procedures. When they arrive in Brazil, the husband accompanies his wife or the first tests and initial consultation, and then the woman remains in the country alone for treatment. If this results in pregnancy, the woman stays to have the baby. When the result is negative, she stays in the country to retry. The process is described as very lonely. Often, the extended family remains unaware of the reason for staying in Brazil due to the stigma associated with infertility (Lazzeri, 2017).

Exactly, because they were all living alone for 9 months in an apartment. I say this from what I'm telling you. I followed it myself. You go there to talk. You understand? You find that 
you are alone: "Oh, I miss my country, I miss my home, I miss my family, I have my life." You understand? So, it was a necessary, but lonely, process. But, it was rewarding for the majority. You could say I accompanied the birth of several children. You could say I was almost a doctor. (L1)

This support of the Angolan community settled in Brazil seems to play a very important role either by establishing the connection with family members who are in Angola, or by facilitating mobility within Brazilian society, with its realm of codes of behavior and local culture. Many women reported receiving support and solidarity from other Angolan women during the process. These contacts have often been made in clinic waiting rooms. For example, in Case 2 reported above, following a meeting in a clinic, E2 moved to live with another Angolan woman when she discovered she was pregnant with twins.

Later, where I was being hosted, I also paid a lot of money. And then, in the clinic, I met other Angolans. I moved from Ibirapuera and went to Brás [two districts of São Paulo city]. And at the clinic where I was, the doctor called it the 'Angolan clinic'. Many Angolans also went to have this treatment and I also met some friends who were there, also expecting a child. A family of all Angolans together, all in the struggle. Then I went for my consultations. Everything went well. I left Brás three months pregnant. I went to São José do Rio Preto [a city, $400 \mathrm{~km}$ from São Paulo] as my brother was there. I wanted to be with the family. (E2, 32 years old, 6 years in treatments in South Africa and Brazil)

Most couples are heterosexual. A community leader mentioned that an unmarried woman came to Brazil in search of treatment. However, single women are exceptional due to gender relations in Angola.

When treatments result in pregnancy or birth of a baby, the news is shared via networks which include Angolan residents in Brazil and other interested parties in Angola. This history of word-of-mouth, this sharing of a lived experience seems to figure as an important element in guiding others in search of reproductive treatment.

After the success, we were sought after by other couples. There is a couple, in particular, that we recommended the same doctor, Dr. [M3], but they have opted for South Africa because the costs are much lower, a lot lower, half. I think at least half those in Brazil. (E1, 47 years old, 10 years of treatments in Portugal and Brazil) 
The announcement of a success was also emphasized by one of the Angolan community leaders in São Paulo, as a practice already observed inside some Pentecostal churches attended by Angolans in Brazil.

These people here often look for churches, and many churches have even acted as agencies for these people: to introduce them for health treatment, to serve as a religious bridge, like a bridge to success. There are many cases that originate from the church. The church says to use a place [clinic], which the pastor recommends, and through trust in the church, the woman has treatment, returns and gives testimony in the church. She has the treatment and it's going well, 'We will not lose any soul'. So, the church plays a very strong role in this, a fundamental role in this. It is not just reproductive treatment. There are diseases that are not receiving treatment in Angola; in the area of health in general. (L1)

This practice of giving testimony because of a 'grace' that has been granted, not only feeds back the trust in religious practice but equally connects individuals to moral-based systems identified with the communities to which they belong.

In addition, undertaking a cycle of assisted reproduction technology involves a complex "ontological choreography" (Thompson, 2005), in which the dynamics of the many and various interrelated factors, such as medical, emotional, relations, cultural, legal, financial, etc., have to be arranged in harmony between everyone involved, and with couples depending upon others who have experience of the processes.

In the quotation below, the patient highlights a TV program produced in Brazil and shown in Angola, as a motivation to come and seek treatment:

It made me come to Brazil -it was mainly for the welfare program - to start having consultations, welfare. [It was because of] the 'Bem Estar' program from Globo [Brazil's largest TV network]. There was a doctor. (...) He talked a lot about fertilization, women's health, and everything. The 'Bem Estar' program. (...) We came here because of this. (E2, 32 years old, 6 years of treatments in South Africa and Brazil)

The couples' evaluation that the quality of assistance given to reproductive health in Angola is poor has led them to make the decision that, after the chronic difficulties of achieving a successful fertilization, 
the woman should remain in Brazil for prenatal care and childbirth and not 'risk' returning to Angola for the delivery:

It's true that we still do not have enough trust in our health system in Angola. My sister, (...) about 2 or 3 years ago, was pregnant with twins. She was having consultations in a clinic, with the doctor. Everything was fine. Six months pregnant, she woke up, her waters had broken, and she had the children - without any explanation. Never had pains, always under care, regular consultations, and suddenly- without explanation. And the doctor simply disappeared and was not there at the time. (...) This is just one of thousands of cases of our health system. Many die...(C1)

\section{FINAL REFLECTIONS}

The impossibility or difficulty to procreate constitutes an undesirable situation, especially for women. In the case of Angolan women, having children is an attribute considered essential for their social recognition. For many infertile women, the absence of IVF access may have significant social consequences. Difficulties with access, the nonexistence of certain services or even the low quality of the assistance for sexual and reproductive health in low income countries, can lead many women to become candidates for a technological solution to respond to their lack of children.

Due to the lack of ART clinics and practitioners in their country, many Angolan couples seek that technological solution in Brazil. The treatment generally takes place in private reproductive clinics in Brazil, but a positive outcome - the birth of a baby-may occur, as mentioned previously, in the public health system, and include the care of the pregnant woman and the temporary monitoring of her newborn's health, as well as the provision of the necessary medicines, without any counterpart of those involved. The need to stay in Brazil for months or years eventually causes, in turn, a kind of 'desocialization' from their own country, since the distance, the solitude and the absence of a coexistent family result in the search for acceptance in the country of infertility treatment. In this context, we can considerer the complex intersections of marginalizing and excluding practices and privilege. This is especially true when we consider cross-border reproduction. A couple may travel abroad because they are excluded from infertility treatment in their home country and privileged to access it in another country. 
Finally, it is in this sense that we can reinforce the idea of 'social construction' of reproductive technologies being mobilized as techniques and instruments. Their use can prevent the breaking-up of marital/emotional and social/cultural bonds between the women who have difficulty getting pregnant, their partners and the communities to which they belong. Far from the justifications built around a pretentious neutrality of science and its biological technologies, fertility treatments should be considered as "assistants of nature".

\section{BIBLIOGRAFÍA}

Alves, S. M. C., et al. (2017). Cooperação internacional e escassez de médicos: análise da interação entre Brasil, Angola e Cuba. Ciência e Saúde Coletiva, 22(7), 2223-2235.

Anvisa (2016). $9^{\circ}$ Relatório do Sistema Nacional de Produção de Embriões. SisEmbrio. Agência Nacional de Vigilância Sanitária. Brasilia. Available at: http://portal.anvisa.gov.br/documents/33840/2817584/10\%C2\%BA+ Relat\%C3\%B3rio+do+Sistema+Nacional+de+Produ\%C3\%A7\%C3\%A3 o+de+Embri\%C3\%B5es+-+SisEmbrio/1121df4c-ab05-47e9-bae0$8 \mathrm{dc} 283 \mathrm{f} 36 \mathrm{fbc}$.

Anvisa (2017). $1^{\circ}$ Relatório de Importação de Amostras Seminais para uso em Reprodução Humana Assistida. Agência Nacional de Vigilância Sanitária. Brasilia. Available at: http://portal.anvisa.gov.br/documents/33840/3484451/1\%C2\%B0+R elat\%C3\%B3rio+de+Importa\%C3\%A7\%C3\%A30+de+Amostras+Semi nais+para+uso+em+Reprodu\%C3\%A7\%C3\%A30+Humana+Assistida 133c91fcf-18bb-4825-b659-a8a45053113f.

Augusto, M. H. O. (1986). Política social e tecnologia em saúde - ação estatal eincorporação de equipamentos médico-hospitalares às práticas de saúde (Tesis Doctoral inédita). Universidade de São Paulo, São Paulo.

Baptista, D. M. T. (2008). Migração na metrópole: o caso dos angolanos em São Paulo. XVI Encontro Nacional de Estudos Populacionais, ABEP. Caxambu.

Banerjee, A. (2014). Raceand a transnationalreproductivecaste system: Indiantransnationalsurrogacy. Hypatia, 29(1), 113-128.

Barbosa, R. M. (1999). Desejo de filhos e infertilidade: um estudo sobre a reprodução assistida no Brasil (Tesis Doctoral inédita). Universidade de São Paulo, São Paulo. 
Boerma, J. T., and Mgalla, Z. (1999). Women and infertility in Sub-Saharan Africa. Reproductive Health Matters, 7(13), 183-188.

CFM (2013). Resolução CFM $n^{\circ}$ 2013/2013. Brasília/DF: Conselho Federal de Medicina. Available at: https://portal.cfm.org.br/images/PDF/resoluocfm\%202013.2013.pdf.

Cooper, M., and Waldby, M. (Eds.). (2014). Clinical Labor: Tissue Donors and Research Subjects in the Global Bioeconomy, Experimental Futures. Durham: Duke University Press.

Culley, L., Hudson, N., y Van Rooij, F. (Eds.). (2009). Marginalized reproduction: ethnicity, infertility and reproductive technologies. London: Earthscan.

Diniz, D. (2003). Tecnologias reprodutivas conceptivas: o estado da arte do debate legislativo brasileiro. Jornal Brasileiro de Reprodução Assistida,7(3), 10-19.

Fonseca, C., and Sá, G. (2011). Apresentação. Ciência, poder e ética: implicações e desdobramentos antropológicos. Horizontes Antropológicos, 17(35), 7-23.

Gerrits, T. (2016). Assisted reproductive technologies in Ghana: transnational undertakings, local practices and 'more affordable' IVF. Reproductive BioMedicine and Society Online, 2, 32-38.

Goodwin, M. B. (Ed.) (2010). Baby markets. Money and the new politics of creating families. New York: Cambridge University Press.

Gürtin, Z., and Inhorn, M. (2011). Introduction: travelling for conception and the global assisted reproduction market. Reproductive BioMedicine Online, 23(5), 535-537.

Hörbst, V. (2016). 'You cannot do IVF in Africa as in Europe': the making of IVF in Mali and Uganda. Reproductive BioMedicine and Society Online, 2, 108-115.

Hörbst, V., and Gerrits, T. (2016). Transational connections of health professionals: medicoscapes and assisted reproduction in Ghana and Uganda. Ethnicity $\in$ Health, 21(4), 357-374.

Hörbst, V., and Wolf, A. (2014). ARVs and ARTs: medicoscapes and the unequal place-making for biomedical treatments in sub-Saharan Africa. Medical Anthropology Quaterly, 28 (2), 182-202.

Ikemoto, L. C. (2009). Reproductive Tourism: equality concerns in the global market for fertility services. Law and Inequality, 27(277), 277-309.

Inhorn, M. (Ed.). (2007). Reproductive disruptions: gender, technology, and biopolitics in the new millennium. Oxford: Berghan Books. 
Inhorn, M. (2011). Globalization and gametes: Islam, assisted reproductive technologies, and the Middle Eastern State. In C. H. Browner and C. Sargent (Eds.). Reproduction, globalization, and the state (pp. 126138). Durham. Duke University Press.

Inhorn, M., and Gürtin, Z. (2011). Cross-border reproductive care: a future research agenda. Reproductive BioMedicine Online, 23(5),665-676.

Inhorn, M., and Patrizio, P. (2015). Infertility around the globe: new thinking on gender, reproductive technologies and global movements in the 21st century. Human Reproduction Update, 21(4), 411-426.

Krolokke, C., Foss, K. A., and Pant, S. (2012). Fertility travel: the commodification of human reproduction. Cultural Politics, 8(2), 273282.

Larsen, U. (2000). Primary and secondary infertility in sub-Saharan Africa. International Journal Epidemiology, 29, 285-291.

Latour, B. (1993). We have never been modern. Cambridge: Harvard University Press.

Lazzeri, T. (2017). De Angola para o Brasil para ter um bebê. Revista Época. 20/01/2016.

Available

at: http://epoca.globo.com/vida/noticia/2016/01/de-angola-por-umbebe.html.

Machin, R. (2014). Sharing motherhood in lesbian reproductive practices. Biosocieties, 9(1), 42-59.

Nahman, M. (2011). Reverse traffic: intersecting inequalities in human egg donation. Reproductive Biomedicine Online, 23, 626-633.

Pfeffer, N. (2011). Eggs-ploiting women: a critical feminist analysis of the different principles in transplant and ferility tourism. Reproductive Biomedicine Online, 23(5), 634-641.

REDLARA. Rede Latino Americana de Reprodução Assistida (2015). Available at: http://redlara.com/aa_portugues/.

Shenfield, F., et al. (2010). Cross border reproductive care in six European countries. Human Reproduction, 25, 1361-1368.

Souza, M.C.B. (2014). Latin America and access to Assisted Reproductive Techniques: a Brazilian perspective. JBRA Assisted Reproduction, 18(2), 47-51.

Spar, D. (2005). Reproductive tourism and the regulatory map. The New England Journal of Medicine, 352(6), 531-533. 
Thompson, C. (2005). Making Parents: The Ontological Choreography of Reproductive Technologies. Cambridge: MIT Press.

Whittaker, A. (2011). Cross-border reproduction care in Asia: implications for access, equity and regulations. Reproductive Health Matters, 19(37), 107-116.

WHO (2016). Estratégia de Cooperação da OMS 2015-2019 Angola. OMS Angola. Escritório Regional Africano. Available at: http://apps.who.int/iris/handle/10665/250516. 